\title{
EESTI KEELE DA-INFINITIIVIS ÖELDISVERBIGA TINGIMUSLAUSED ${ }^{1}$
}

\author{
Helen Plado \\ Tartu Ülikool
}

Kokkuvõte. Artikkel tutvustab tingimuslauseid, mille öeldisverb on $d a$-infinitiivi vormis. Vastatakse küsimustele, milliste vahenditega sellises lauses hüpoteetilisuse astet väljendatakse, millistes funktsioonides saab $d a$-infinitiivse öeldisverbiga tingimuslauseid kasutada ning kas isiku-, aja- ja kõneviisikategooriaga markeerimata verbivormi kasutus tingimuslauses muudab lause geneeriliseks. Uurimus näitab, et $d a$-infinitiivis öeldisverbiga tingimuslause eristub finiitse predikaadiga tingimuslausest mitmes mõttes. Lause hüpoteetilisuse aste järeldub suures osas pealause predikaadi vormist. Kui pealause öeldisverb on indikatiivis, on lausel enamasti madal hüpoteetilisuse aste; kui aga konditsionaalis, siis on kogu lausel sageli kõrgem hüpoteetilisuse aste. Lause hüpoteetilisuse astet võib lisaks pealause öeldisverbi kõneviisile mõjutada ka muude vahenditega, nt teatud adverbide või pealauses mineviku kasutamisega. $d a$ infinitiivse predikaadiga sisulisi tingimuslauseid esineb üsna vähe ning $d a$-infinitiivse öeldisverbiga episteemilisi tingimuslauseid ei esine uuritavas materjalis üldse. Kõige sagedamini kasutatakse $d a$-infinitiivset öeldisverbi konversatsioonilistes tingimuslausetes. Sisulistes tingimuslausetes muudab $d a$-infinitiivse predikaadi kasutus kogu lause geneeriliseks, kuid konversatsiooniliste tingimuslausete puhul saab lause siiski mittegeneerilise tõlgenduse. $d a$-infiniitse predikaadi semantiliseks subjektiks on indefiniitne inimene, kes konversatsiooniliste tingimuslause korral osaleb tõenäoliselt suhtlussituatsioonis.

Märksõnad: eesti keel, süntaks, adverbiaallause, tingimuslause, $d a$-infinitiiv, geneerilisus

\footnotetext{
${ }^{1}$ Uurimust on toetanud ETFi grant nr 2007. Tänan oma juhendajat emeriitprofessor Mati Ereltit ja doktor Liina Lindströmi asjalike ning mõtlema- ja arutlemapanevate kommentaaride eest. Minu tänu kuulub ka Leila Smithsonile abi eest inglise keelega.
} 


\section{Sissejuhatus}

Infinitiive on sageli käsitletud piirinähtusena substantiivi ja verbi vahel (vt nt Erelt 1984 ja Itkonen 2001: 144 jt). Sellele vaatamata on eesti keele teatud konstruktsioonides võimalik kasutada $d a$-infinitiivi vormis verbi iseseisva predikaadina. Käesolev artikkel kirjeldabki üht sellist juhtu - eesti keele $d a$-infinitiivi vormis öeldisverbiga tingimuslauseid. Artikkel otsib vastust küsimusele, kas $d a$-infinitiivis öeldisverbiga tingimuslause erineb indikatiivis ja konditsionaalis predikaadiga tingimuslausest. Et $d a-$ infinitiiviga ei seostu kõneviisikategooria, tekib küsimus, milliste vahenditega hüpoteetilisuse astet väljendatakse. Samas huvitab ka see, kas $d a$-infinitiivse öeldisverbiga tingimuslauseid saab kasutada kõikides samades funktsioonides kui finiitse predikaadiga tingimuslauseid, ning kas isiku-, aja- ja kõneviisikategooriaga markeerimata verbivormi kasutus tingimuslauses muudab lause geneeriliseks.

Traditsioonilise arusaama järgi ei ole mittepöördelised verbivormid (infinitiivid, partitsiibid ja konverbid) vastupidiselt pöördelistele verbivormidele markeeritud isiku-, arvu-, aja-, kõneviisi- jm kategooriatega või siis avalduvad need kategooriad teisiti kui pealause finiitverbi puhul (Cristofaro 2007: 98) ning infiniitsed verbivormid ei saa esineda iseseisva predikaadina (Koptjevskaja-Tamm 1993: 29). Mittepöördeliste verbivormide olulise tunnusena tuuakse välja ka see, et puudub eksplitsiitne subjekt, millega verb ühilduks, või kui subjekt on, siis erineb see iseseisva lause subjektist (Koptjevskaja-Tamm 1999: 147). Infiniitne verbivorm saab isiku-, aja- ja modaalsustähenduse finiitse verbivormiga väljendatud tegevuse kaudu (Erelt 1984: 4).

Infinitiivid on lauses tüüpiliselt finiitverbi seotud laiendid (vt nt Noonan 1985, Erelt 1987: 13 ja Ylikoski 2003: 197). Siiski võivad infinitiivid teatud juhtudel esineda ka iseseisva öeldisverbina, ja seda isegi pealauses, nagu on näidanud Nikolaeva (2007), Visapää (2008) ja ka Erelt (1984). Eesti keeles võib dainfinitiiv esineda iseseisva predikaadina siiski enamasti teatud kõrvallausetes, sh ka mõningates adverbiaallausetes: tingimus(1), otstarbe- (2) ja vastandavas kõrvutuslauses (3). Kui otstarbelauses ja vastandavas kõrvutuslauses on $d a$-infinitiiv pealausega 
samasubjektiline, siis tingimuslauses puudub $d a$-infinitiivi subjektil viiteseos pealause subjektiga. (EKG II: 244-246)

(1) Kui krässid mõni päev varem valmis teha, kuivavad kartulid kiiresti ja kergeks. AJAE1990lep0174 ${ }^{2}$

(2) Vaevaga-vaevaga otsib ta padja alt pilti, et seda vaatama hakata. ILU1990lilu0001

(3) Ühesõnaga, selle asemel et püsti karata, restoranist väljuda, liftiga numbrituppa sõita, asjad spordikotti loopida ja esimese lennukiga koju kihutada, ei nihutanud mina isegi tooli. ILU1990)ilu0584

Näib, et $d a$-infinitiivi on iseseisva predikaadina hakatud kasutama suhteliselt hiliselt; 17. sajandi kirjakeele tekstides ei leidu lauseid, kus da-infinitiivi oleks predikaadina kasutatud (Penjam 2008). 20. sajandi alguseks on $d a$-infinitiivi taoline kasutus aga juba tuttav (4).

(4) Kui Helsingi uut Lutheri kirikut waadata, siis hüppab süda ja silm rõõmu pärast, nii ilus on ta. AJA1900laja0095

Tingimuslauseis, mis on markeeritud verbialgulisusega, ei saa öeldisverb olla $d a$-infinitiivi vormis. Näiteks kui verbialgulisusega markeeritud tingimuslauses (5) muuta predikaat $d a-$ infinitiivseks, muutub lause ebagrammatiliseks (5'). da-infinitiivne öeldiverb on aga võimalik, kui markeerida tingimuslause konjunktsiooniga kui (5').

(5) Lähed sinna reisibüroo kaudu, ei ole viisat vaja.

(5') *Minna sinna reisibüroo kaudu, ei ole viisat vaja.

$(5$ ') Kui minna sinna reisibüroo kaudu, ei ole viisat vaja.

Artiklis vaadatakse kõigepealt, milliste vahenditega lause hüpoteetilisuse astet väljendatakse. Finiitse öeldisverbiga tingimuslause puhul on levinuimaks hüpoteetilisuse astme väljendajaks tingimuslause öeldisverbi kõneviis, kuid lause hüpoteetilisuse astme tõlgendust mõjutab ka pealause öeldisverbi kõneviis (Koks 2006). Et $d a$-infinitiiv ei seostu kõneviisikategooriaga,

\footnotetext{
${ }^{2}$ Näitelaused on võetud TÜ kirjakeele korpusest, täpsemalt vt jaotisest 2.
} 
vaadatakse, kas pealause predikaadi kõneviis muutub oluliseks hüpoteetilisuse astme väljendajaks. Seejärel tutvustatakse teisi käsitletavast väikesemahulisest keelematerjalist ilmnenud grammatilisi ja leksikaalseid vahendeid, mille abil on võimalik hüpoteetilisuse astet väljendada. $d a$-infinitiivse öeldisverbiga tingimuslausete funktsioonide kirjeldamiseks näidatakse, milliseid verbe eri funktsionaalsete tüüpide puhul kasutatakse, ning seejärel kirjeldatakse keelematerjalis esinevaid tüüpe eraldi. Viimasena näidatakse, kas see, et tingimuslauses kasutatakse $d a-$ infinitiivi, mis on isiku-, aja- ja kõneviisikategooriaga markeerimata verbivorm, muudab kogu lause geneeriliseks; seejuures käsitletakse eraldi eri funktsionaalset tüüpi tingimuslauseid.

\section{Keelematerjal}

Keelematerjal on pärit Tartu Ülikooli eesti kirjakeele korpuse 1990. aastate ilu- (näitlausetes ILU1990) ja ajakirjanduskeele (näitelausetes AJA1990) allkorpusest. Ilukirjanduskeele korpuses oli 1628 ja ajakirjanduskeele korpuses 1691 sidesõnaga kui markeeritud tingimuslauset, neist $d a$-infinitiivis öeldisverbiga tingimuslauseid vastavalt 100 ja 158 . Kui ühes liitlauses esineb rohkem kui üks kui-konjunktsiooniga kõrvallause, loen need eri juhtudeks. Üheks terviklikuks tingimuslauset sisaldavaks liitlauseks loen ka need juhud, mil pea- ja kõrvallause on vormistatud eri lausetena (6). Analüüsist jätan aga välja ühe ilukirjanduskeele tingimuslause, millel puudub pealause.

(6) „Ülemine pool vihjab täielikule taandarengule,” kritiseeris kivinaine, kelle nägu Hermani õuduseks meenutas Silva Anderssoni. Muidugi kui too igast suunast tublisti välja venitada. ILU1990〈ilu0284

\section{3. da-infinitiivis öeldisverbiga tingimuslausete hüpo- teetilisuse aste}

Tingimuslauseid (edaspidi TL) on jaotatud mitmeti. Kõige sagedamini liigitatakse tingimuslaused reaalseteks ja irreaalseteks. 
Irreaalsed TL-d jaotatakse enamasti veel kaheks: hüpoteetilisteks ja kontrafaktiivseteks. Reaalsed TL-d väljendavad reaalselt eksisteerivaid või eksisteerinud tingimusi. Irreaalsed TL-d väljendavad tingimusi, mis kõnehetkel ei eksisteeri, kuid mille puhul kujutletakse, mis võiks (hüpoteetilised TL-d) või oleks võinud (kontrafaktiivsed TL-d) olla. Siin lähtun aga Comrie (1986: 88-89) käsitlusest, mis väidab, et hüpoteetilisus on kontiinum ning seetõttu ei ole võimalik tõmmata tüüpide vahele selgeid piire. Comrie eeskujul analüüsin lausete hüpoteetilisuse astet. Kõrgem hüpoteetilisuse aste tähendab väiksemat tõenäosust ja madalam hüpoteetilisuse aste suuremat tõenäosust. Nii et faktidele vastav lause esindab madalaimat ning kontrafaktiivne lause kõrgeimat hüpoteetilisuse astet.

Käsitletavast keelematerjalist nähtub, et lause hüpoteetilisuse aste järeldub suuresti pealause predikaadi vormist. Seetõttu jätan selles osas analüüsist välja tingimuslaused, mil puudub pealauses öeldisverb (ühtekokku 11 lauset).

Kui kindlas kõneviisis öeldisverbiga tingimuslause võib väljendada nii madalat kui ka kõrgemat hüpoteetilisuse astet (Koks 2006), siis $d a$-infinitiivis öeldisverbiga tingimuslauseil, mille pealause öeldisverb on indikatiivis, on enamasti madal hüpoteetilisuse aste, väljendades meid maailmas ümbritsevaid seaduspärasusi või sisaldades mõnd harjumuslikku/üldist või sageli korduvat situatsiooni (7-8). On ka lauseid, mis küll ei väljenda ei seadus- ega harjumuspärast situatsiooni, kuid millel on siiski madal hüpoteetilisuse aste (9). Siiski võib mõningates lausetes olla tegemist ka kõrgema hüpoteetilisuse astmega. Sel juhul kujutatakse võimalikku situatsiooni ette, kuigi teatakse, et suure tõenäosusega tingimuslausega edasiantu ei toimu, või peetakse selle toimumist ebatõenäoliseks (10). (10)-taolisi lauseid esineb äärmiselt harva.

(7) Kui teha omlett 3-4 sööjale 6 munast, peab selleks olema suur ümmargune pann. AJAE1990\stak0420

(8) Paari-kolme rubla eest oli mul põõsastesse peidetud taarat, mida aeg-ajalt ikka leiab, kui käia ringi lahtiste silmadega. ILU1990)ilu0578 
(9) Kui esialgne ärritus ära ajada ja nimekirju täiesti rahulikult lugeda, nähtub, et inimesi, kelle kohta midagi ütelda ei oska, mõningal määral on. AJAE1990\stak0237

(10) Iga laps ju teab, et kui sõita valguse kiirusel, siis saab ajas tagasi minna. ILU1990lilu0181

Tingimuslauseid, mille öeldisverb on $d a$-infinitiivi vormis ning mille pealause öeldisverb on tingivas kõneviisis, on keelematerjali hulgas 35 . Need laused võivad väljendada nii madalat kui ka kõrget hüpoteetilisuse astet. Kui lausesse (11) ei lisa pealause konditsionaalne finiitverb mitte hüpoteetilisust, vaid ettevaatlikkust, pehmendades nii lausega väljendatut, siis lausetes (12-13) lisatakse pealause öeldisverbi konditsionaali abil hüpoteetilisust ning lausega kujutletakse, mis võiks olla, kui tingimuslausega edasi antud tingimused oleksid täidetud. Seejuures võidakse lausega väljendatu toimumist pidada kas tõenäoliseks (12) või ebatõenäoliseks (13).

(11) Olen tähele pannud, et kui looduslikust materjalist mingit kuju valmistada, ei tohiks sellele anda väga peent viimistlust ja suurt sära - nii kaotab teos inimesele midagi väga sooja ja lähedast. AJAE1990lep0135

(12) Kui projekteerijalt tellida universaalne saal, oleks võimalike kontsertetenduste diapasoon lai, galakontserdist rändtsirkuseni. AJA1990led0011

(13) „Ämmatoss... ämmatoss!” karjusid poisikesed talle järele ja arutasid, kuidas ta susisedes õhupallina kokku vajuks, kui põõsastest talle nool keresse kihutada. ILU1990lilu0079

Kahes lauses oli pealause öeldisverb tingiva kõneviisi minevikus, muutes nii kogu lause kontrafaktiivseks, st on teada, et sellega väljendatu ei täitunud (14).

(14) Võib-olla tõesti poleks meil olnud vaja seda referendumit teha, kui otseselt lähtuda õiguslikust järjepidevusest. AJAE1990\tat0676 
Lisaks pealause öeldisverbi tingivale kõneviisile võib $d a$ infinitiivse predikaadiga tingimuslause hüpoteetilisuse astet muuta ka nt adverbidega (15-16) või pealause predikaadi kaudse kõneviisi (17) või minevikulise ajavormiga (18). Lauses (15) tõstetakse lause hüpoteetilisuse astet adverbiga näiteks, mis näitab, et kujutletakse vaid, mis võiks olla.

(15) Kui näiteks kanda raha oma spordiühingu arvele ja minna selle eest sõbratariga Havai saarele surfama, siis on see justkui spordile antud, tõi ta näite ja lisas: Samas pole neil riigi ees mitte mingit kohustust. AJAE1990lep0025

Lauses (16) tõstetakse aga adverbiga alati lause tõenäosuse astet, viidates situatsiooni korduvusele ja tavapärasusele.

(16) Pealegi kui lähemalt uurima hakata, selgub alati, et inimese pea ei ole sugugi mingi sile geomeetriline vorm - oh ei, nad on lõputult liigendatud ja alati kordumatud. ILU1990 lilu0602

17. näitelauses lisab kahtlusevarjundit ja ühtlasi tõstab lause hüpoteetilisuse astet kvotatiivi kasutamine pealauses.

(17) Kui taim, tema hing ja sõna kokku sõlmida, siis koos saavat nad kõige raskemastki jagu. ILU1990lilu0065

Pealause öeldisverbi minevikuline ajavorm vähendab lause hüpoteetilisuse astet; kui pealause öeldisverb on minevikuline, siis on teada, et lausega väljendatu on toimunud ning seega on lause väga kõrge tõenäosuse astmega (18) (vt ka Thompson ja Longacre 1985: 190-191).

(18) Kui saepuru täis rusikas kõvasti kinni suruda, võis peopesas tunda hämarat rahustavat niiskust .. ILU1990lilu0023 


\section{4. $d a$-infinitiivse öeldisverbiga tingimuslausete funktsioonipõhine analüüs}

\subsection{Tingimuslause funktsionaalsed tüübid}

Mitmeid adverbiaallauseid, sh ka tingimuslauseid võib jagada sisulisteks, episteemilisteks ja konversatsioonilisteks adverbiaallauseteks (vt nt Plado 2008). Sisutasandi TL-d (19) väljendavad pealausega edasi antud sündmuse toimumise tingimust. Episteemiliste TL-te (20) puhul on kõrval- ja pealause vahel järeldussuhe; kui on teada, et tingimuslausega väljendatu toimub, siis võib sellest järeldada, et toimub ka pealausega edasiantu (Sweetser 1990: 116). Konversatsiooniliste TL-te hulka kuuluvad kõneaktitingimuslaused (21) ja metakeelsed tingimuslaused (22). Konversatsioonilised TL-d ei anna edasi kõrval- ja pealause vahelist tingimussuhet, vaid kommenteerivad pealausega esitatut, muutes selle suhtlussituatsioonis relevantseks või väljendades sellega edasiantu sobivust (Dancygier 2006: 105).

(19) Kui nende külge hooratas ühendada, võiks ju kärusse viljaveski ehitada! ILU1990lilu0644

(20) Aken peab lahti olema, kui nii vali müra kuulda on. ILU1990)ilu0287

(21) See on alatu, kui teada tahad! ILU1990lilu0032

(22) Ta on teravam, tänapäevasem, moodsam - kui niisugune sõna on siin omal kohal. ILU1990lilu0612

\subsection{Verbid $d a$-infinitiivse predikaadiga tingimuslauseis}

Et eri funktsionaalset tüüpi tingimuslauseis kasutatakse predikaadina eri verbe, jagan verbid Pajuneni (2001: 51-59) käsitlusest lähtudes kaheks: verbid, mis väljendavad konkreetset tegevust, seisundit, sündmust (A-verbid), ja verbid, mis väljendavad mentaalset tegevust, seisundit, sündmust (B-verbid); B-verbide hulka kuuluvaks peetakse ka kirjaliku kultuuriga seotud verbe.

$d a$-infinitiivse öeldisverbiga tingimuslausetes kasutatakse tunduvalt enam B-verbe. B-verbidega tingimuslauseid oli 182 ja 
A-verbidega 70. Lisaks esines 5 korral tingimuslausena vormel kui nii võtta (23).

(23) Kui nii võtta, siis oli see ju tavaline lennuõnnetus, kuigi pisut ebatavalistel asjaoludel. ILU1990lilu0151

B-verbide hulgas tulid selgesti esile enim kasutatavad tegusõnad: mentaalset tegevust väljendavad verbid mõtlema või järele mõtlema (23 korral; näide 24) ja arvestama või arvesse võtma (22 korral; 25-26), maha / välja / hulka arvama (9 korda; 27), meenutamal meelde tuletama (8 korda; 28), vaatama (8 korda; 29), võrdlema (7 korda; 30); verbaalset tegevust edasi andev verb rääkima (9 korda; 31$)$ ning mentaalset seisundit väljendav verb olema (9 korda; 32).

(24) Kui järele mõelda, siis olen oma elu ikka elanud kahe linna vahel. AJAE1990\tat0743

(25) Kui arvestada, et bussisõit on prii ja toit tasuta, pole seda raha vist sugugi nii vähe. AJA1990〈pp0071

(26) See oligi kogu nende majapidamine, kui mitte arvestada suurt võlvkeldrit maja taga õues. ILU1990lilu0066

(27) Või põen ma suurusehullustust nagu meie suurepärane poeet Juhan Liiv, kelle olemasolu nad ei aimagi ja kes ei jõudnud (kui üks pooläpardunud Varssavi-sõit välja arvata! ) Eestimaa piiridest kaugemale? ILU1990lilu0261

(28) Mõistagi ei möödu see valutult, vahel üsnagi traagiliselt, kui meenutada endiste riigijuhtide saatust Rumeenias, Bulgaarias, Saksa DV-s. AJA1990\re0215

(29) Kui vaadata seniseid riigi otsuseid, siis tundub küll, et majanduslik põhjendatus on pidanud taanduma kas hetkehuvide või sõpradele vastutuleku ees. AJAE1990lep0191

(30) Kui võrrelda liha hindu omavahel, siis praegu on nii sea-, veise- kui lambaliha enam-vähem sama. AJA1990\ml0147

(31) Kui sulle õigust rääkida, siis on mul koguni hea meel, et asjad nii kulgevad ning lõpuks ühele poole saavad. ILU1990lilu0600

(32) Muid muljeid on palju, aga kui aus olla, saab neid Setumaalt enam, kaugematest nurkadest kõnelemata. AJA1990 $\checkmark \mathrm{re} 0209$ 
A-verbidest esineb tingimuslause $d a$-infinitiivis predikaadina füüsilist tegevust väljendavad (38 korda; näide 33) ja muud konkreetset tegevust väljendavad verbid (32 korda; 34).

(33) Ent kui samasugune kauss teha näiteks katkisest savikausist, tuleks see katta ka seestpoolt. AJAE1990lep0221

(34) Toronto töörühma arvates võiks Eesti valitsus ajada väga edukat majanduspoliitikat juhul, kui uute eraettevõtete esimestel aastatel nad täielikult tulumaksust vabastada.

AJA1990lee 0450

\section{3. $d a$-infinitiivse öeldisverbiga tingimuslausete funktsionaalsed tüübid}

Kui finiitse öeldisverbiga tingimuslausete puhul on kõige sagedasemaks sisutasandi tingimuslaused, siis $d a$-infinitiivis öeldisverbiga tingimuslausete puhul ei ole need sagedasimaks. Sisulisteks tingimuslauseteks on peamiselt need, mille predikaadiks on A-verb (35), kuigi neis võivad esineda ka teatud tüüpi B-verbid (36).

(35) Loomulikult oleks põlevkivist põhimõtteliselt võimalik saada ka kõikidele nõuetele vastavat bensiini, kui põlevkivi toorõli vastavalt töödelda. AJA1990\ol1637

(36) Katus ulatub maani, nii et kui väljast vaadata, siis ongi ainult katus; indiaanlastel on hoone tehtud pühvlinahkadest, aga tema, Mihkel teeb selle laudadest. ILU1990lilu0669

Episteemilisi $d a$-infinitiivse öeldisverbiga tingimuslauseid käsitletavas suhteliselt väikesemahulises keelematerjalis ei esine. Need näivad olevat äärmiselt harvad, kuid siiski võimalikud. Näiteks lause (37) on teatud situatsioonis mõeldav.

(37) Kui siit kirikutorni näha, on nägemine korras.

$d a$-infinitiivse predikaadiga episteemiliste tingimuslausete vähesuse põhjusi tuleb otsida järeldamise iseloomus. Järeldusi tehakse sageli teatud olukorra põhjal (kui tuli põleb, on ta kodus; 
kui tänavad on märjad, on öösel vihma sadanud jne), kuid dainfinitiivse predikaadi „subjektiks" on inimene; teiseks tehakse järeldusi enamasti konkreetses situatsioonis, kuid $d a$-infinitiivne predikaat muudab tingimuslause sageli geneeriliseks.

$d a$-infinitiivis öeldisverbi saab kasutada nii kõneakti- (38) kui ka metakeelsetes tingimuslausetes (39).

(38) Kui murest rääkida, siis ratastraktorist on küll suur puudus. AJA1990ไrh1565

(39) Tõsi küll, natuke aeglaselt, sest loodusteaduslikud huvid konkureerisid utilitaarsetega, kui peenelt öelda. ILU1990 ilu0298

Konversatsiooniliste tingimuslausete piirialale kuuluvaks võib pidada tingimuslauseid, mis ei väljenda küll selgelt, millist kõneakti pealausega sooritatakse, kuid millel on sageli sama ülesanne kui kõneaktitingimuslausel, st need muudavad pealausega väljendatu suhtlussituatsioonis relevantseks (40) või esitavad uue teema, mille kohta pealausega midagi väidetakse (41). Samas võivad need ka seletada, miks pealausega edasiantut öeldakse; näites (42) seletatakse tingimuslausega, miks peetakse nimesid ,Kiigadi' ja ,Kaagadi' sobivamateks. Näide (40) on lähedane tüüpilisele kõneaktitingimuslausele. Lisaks sisulisele sarnasusele on see ka vormistatud samamoodi kui kõneaktitingimuslause, st tingimuslause ei esita pealausega väljendatu toimumise tingimust (nagu sisutasandi tingimuslause), kuid seda on võimalik sisutasandi tingimuslausena parafraseerida (40'). Selliste tingimuslausete predikaadiks on tavaliselt mentaalset tegevust või seisundit väljendav verb.

(40) Kui asja eetilisest küljest kaaluda, siis on kõigi riikide julgeolekuorganid üks ja sama asutus. ILU1990lilu0199

(40') Kui asja eetilisest küljest kaaluda, siis võib öelda/nõustuda, et kõigi riikide julgeolekuorganid on üks ja sama asutus.

(41) Kui võtta teiste riikide sportlasi, siis jäi küll selline mulje, et lausa segased medalite järele. AJA1990\m10157 
(42) 'Kiigadi' ja 'Kaagadi' oleks natuke parem, kui mõelda sellele, et kõnealused peegelkaksikud tantsivad korra, veel parem ehk 'Trillallaa' ja 'Trallallaa', kuna vennaksed ju on üsna tühikargajad. AJA19901k10264

On ka tingimuslauseid, mis sisuliselt meenutavad küll kõneaktitingimuslauseid, kuid mis on vormistatud sisutasandi tingimuslausena (43), st tingimuslause väljendab pealausega väljendatud sündmuse toimumise tingimust. Vrd sama lauset, mis on vormistatud kõneaktitingimuslausena (43').

(43) Kui sellest lähtudes hinnata EPMÜ 1994. a. teadusalase baasfinantseerimise plaane ja Eesti Teadusfondi uurimistoetusi, peame paraku tõdema: need olid tõeline investeering minevikku. AJA1990\k10244

(43’) Kui sellest lähtudes hinnata EPMÜ 1994. a. teadusalase baasfinantseerimise plaane ja Eesti Teadusfondi uurimistoetusi, siis need olid tõeline investeering minevikku.

Nii võibki mentaalset tegevust ja seisundit väljendavaid tingimuslauseid pidada vahealaks sisuliste ja kõneaktitingimuslausete vahel.

\section{5. $d a$-infinitiivse öeldisverbiga tingimuslause geneeri- lisuse väljendajana ${ }^{3}$}

Geneerilisusest rääkides tuleb vahet teha geneerilisel fraasil ning geneerilisel lausel. Geneeriline fraas ei pruugi muuta kogu lauset geneeriliseks. Näites (44) on geneeriline fraas about the potato 'kartulist', kuid seda kasutatakse lauses, mis viitab konkreetsele situatsioonile. (Behrens 2005: 288-289)

(44) Yesterday, we had a very interesting discussion about the potato. 'Eile oli meil väga huvitav vestlus kartulist'

\footnotetext{
${ }^{3}$ See on osa Hanna Jokela ja Helen Plado ühisest uurimusest, mis käsitleb geneerilisi tingimuslauseid soome ja eesti keeles.
} 
Siin keskendutakse eelkõige geneerilisele lausele, kuid heidetakse pilk ka tingimuslause $d a$-infinitiivse öeldisverbi subjektile.

Geneeriline lause ei kirjelda mitte konkreetset sündmust ega objekti, vaid üldist situatsiooni või fakte (Krifka 1999: 169) ning välistab ajaviite konkreetsele hetkele (Cardinaletti ja Starke 1999: 157) (45).

(45) Ent kui samasugune kauss teha näiteks katkisest savikausist, tuleks see katta ka seestpoolt. AJAE1990lep0221

Langacker (1997) kõrvutab geneerilisi situatsioone harjumuslikega ning leiab, et nende eristamine on sageli kunstlik, sest geneerilisus sisaldab tavaliselt ka harjumuspärasust (ja seega ka korduvust). Seetõttu ei eristata siinses käsitluses geneerilisi ja harjumuslikke situatsioone kirjeldavaid lauseid.

Et infinitiivil ei ole eksplitsiitset subjekti ega ajamarkeeringut, näib see olevat sobiv vahend geneerilisuse väljendamiseks. Sama on soome keele põhjal näidanud Visapää (2008), kes väidab, et A-infinitiivi subjekt on alati geneeriline ja et infinitiiv muudab kogu verbiga väljendatud protsessi atemporaalseks. Ka Jokela (2006: 66-67) uurimusest selgub, et soome keele geneerilise nollapersoona-konstruktsiooniga tingimuslauset tõlgitakse eesti keelde sageli $d a$-infinitiivis öeldisverbiga tingimuslausega.

Kuigi $d a$-infinitiivi kasutus muudab eesti keele tingimuslause geneeriliseks, mängib kogu lause tõlgendamisel kas geneeriliseks või kindla situatsiooniga seotuks rolli ka pealause ning kontekst.

Sisulise tingimuslause korral muudab tingimuslause $d a$ infinitiivis öeldisverb enamasti kogu lause geneeriliseks. Tegevussubjekt on indefiniitne, kuid on teada, et selleks on inimene. Analüüsitud materjali hulgas ei olnud ühtegi lauset, kus tingimuslause füüsilist tegevust väljendava $d a$-infinitiivse öeldisverbi korral oleks lause olnud seotud konkreetse ajahetke või sündmusega, vaid kõik laused olid geneerilised (46). Konkreetset mittefüüsilist tegevust väljendavate $d a$-infinitiivse öeldisverbiga tingimuslausete hulgas oli üksikuid lauseid, mille puhul muudab kontekst kogu lause tõlgenduse mittegeneeriliseks (47). Kui tingimuslause kui kirjastamisega veidikene kiirustada on geneerili- 
ne, siis kontekst seob selle konkreetse situatsiooniga ja annab ka viite konkreetsele ajahetkele, muutes seega kogu lause mittegeneeriliseks. $d a$-infinitiivse öeldisverbiga seotud tegevussubjekt jääb aga endiselt indefiniitseks.

(46) Kui kunstlik sülem raamile paigutada, siis tagab loomulik töö kärje ehitamisel ja paljunemine pere edasise elujõulisuse. AJA1990\ml0096

(47) Sel sügisel on Kalju Saaberil valmimas koguteose Virumaa käsikiri. Kui kirjastamisega veidikene kiirustada, on võimalik üllitis päevade alguseks välja anda. AJAE1990lep0016

Ka konversatsioonilise tingimuslause korral muudab $d a$ infinitiivis öeldisverb tingimuslause geneeriliseks, kuid kogu lause saab siiski enamasti mittegeneerilise tõlgenduse. Näiteks lause (48) tingimuslause kui võrrelda meeste ja naiste võidutulemusi näib olevat atemporaalne, st kehtib igal ajahetkel, ning selle tegevussubjekt võiks olla ükskõik kes, kuid pealause seob terve lause konkreetse sündmusega ja kitsendab tegevussubjekti referenti kellekski suhtlussituatsioonist. Taolise tõlgenduse juures mängib rolli ka konversatsioonilise tingimuslause funktsioon (muudab pealausega väljendatu suhtlussituatsioonis relevantseks, esitab uue teema, mille kohta pealausega midagi väidetakse, või seletab, millele toetudes pealausega edasiantut öeldakse), mis seob selle konkreetse suhtlussituatsiooniga. $d a$-infinitiivis öeldisverbi tegevussubjekt on indefniitne, kuid on teada, et see on inimene, kes tõenäoliselt on suhtlussituatsiooni osaline.

(48) Kui võrrelda meeste ja naiste võidutulemusi, siis tunduvad tugevama poole näitajad suhteliselt tagasihoidlikuna: kaugus 8.30, kõrgus 2.31, kolmik 17.26, $100 \mathrm{~m} \mathrm{10,24.}$ AJAE1990\stak0367

\section{Kokkuvõte}

$d a$-infinitiivis öeldisverbiga tingimuslause eristub indikatiivse ja konditsionaalse predikaadiga tingimuslausest mitmes mõttes. Et $d a$-infinitiiv kõneviisitähendust ei kanna, järeldub lause hüpotee- 
tilisuse aste peamiselt pealause predikaadi vormist. Kui pealause öeldisverb on indikatiivis, on lausel enamasti madal hüpoteetilisuse aste; kui aga konditsionaalis, siis on kogu lausel sageli kõrgem hüpoteetilisuse aste. Siiski võib pealause tingivas kõneviisis predikaat hüpoteetilisuse astme tõstmise asemel lisada lausesse ettevaatlikkust või viisakust. Lause hüpoteetilisuse astet võib lisaks pealause öeldisverbi kõneviisile mõjutada ka muude grammatiliste ja leksikaalsete vahenditega, nt teatud adverbide (nt alati) või pealauses mineviku kasutamisega.

Kui sisulistes tingimuslausetes esineb $d a$-infinitiivset predikaati suhteliselt vähe (arvestades sisuliste tingimuslausete sagedust), siis $d a$-infinitiivse öeldisverbiga episteemilisi tingimuslauseid uuritavas materjalis ei esinenud üldse. Kõige sagedamini kasutatakse $d a$-infinitiivset öeldisverbi konversatsioonilistes tingimuslausetes. Lisaks prototüüpsetele kõneakti- ja metakeelsetele tingimuslausetele moodustavad konversatsiooniliste tingimuslausete hulgas omaette (ja ühtlasi arvukaima) rühma tingimuslaused, mis täidavad küll konversatsiooniliste tingimuslausete ülesandeid, kuid mis ei anna infot selle kohta, millist kõneakti pealausega sooritatakse. Sisulistes tingimuslausetes muudab $d a$ infinitiivse predikaadi kasutus kogu lause geneeriliseks, kuid konversatsioonilistes tingimuslausetes muudab see geneeriliseks küll tingimuslause, kuid terve lause saab siiski mittegeneerilise tõlgenduse.

$d a$-infinitiivse predikaadi semantiliseks subjektiks on indefiniitne inimene, kes konversatsiooniliste tingimuslause korral osaleb tõenäoliselt suhtlussituatsioonis.

Kuigi $d a$-infinitiivset öeldisverbi on võimalik kasutada nii sisulistes, konversatsioonilistes kui ka episteemilistes tingimuslausetes, on see siiski enim kinnistunud konversatsioonilistesse tingimuslausetesse.

\author{
Helen Plado \\ Tartu Ülikool \\ Eesti ja üldkeeleteaduse instituut \\ Ülikooli 18, 50090 Tartu \\ Helen.Plado@ut.ee
}




\section{Kirjandus}

Behrens, Leila (2005) "Genericity from a cross-linguistic perspective". Linguistics 43, 2, 275-344.

Cardinaletti, Anna, Michal Starke (1999) "The typology of structural deficiency: A case study of the three classes of pronouns". Henk van Riemsdijk, toim. Clitics in the languages of Europe, 145-233. Berlin, New York: Mouton de Gruyter.

Comrie, Bernard (1986) "Conditionals: A typology". Elizabeth Traugott, Alice ter Meulen, Judy Snitzer Reilly, Charles A. Ferguson, toim. On conditionals, 77-99. Cambridge: Cambridge University Press.

Cristofaro, Sonia (2007) "Deconstructing finiteness: finiteness in a functional-typological perspective". Irina Nikolaeva, toim. Finiteness. Theoretical and empirical foundations, 91-114. Oxford: Oxford University Press.

Dancygier, Barbara (2006) Conditionals and prediction. Time, knowledge and causation in conditional constructions. Cambridge: Cambridge University Press.

EKG II = Erelt, Mati, Reet Kasik, Helle Metslang, Henno Rajandi, Kristiina Ross, Henn Saari, Kaja Tael, Silvi Vare. Eesti keele grammatika II. Süntaks. Lisa: kiri. Trükki toimetanud Mati Erelt (peatoimetajana), Tiiu Erelt, Henn Saari, Ülle Viks. Tallinn: Eesti Teaduste Akadeemia Keele ja Kirjanduse Instituut, 1993.

Erelt, Mati (1984) da-infinitiivi süntaktilised funktsioonid tänapäeva eesti keeles. Soome-eesti kontrastiivseminar (Helsingi, 17.20.10.84). (Preprint KKI-24.) Tallinn: Eesti NSV Teaduste Akadeemia.

Erelt, Mati (1987) Sekundaartarindid eesti keeles. (Preprint KKI-50.) Tallinn: Eesti NSV Teaduste Akadeemia.

Itkonen, Esa (2001) Maailman kielten erilaisuus ja samuus. (Yleisen kielitieteen julkaisuja 4.) Turku: Turun Yliopisto.

Jokela, Hanna (2006) "Geneerinen nollasubjektilause suomessa ja virossa”. Krista Kerge, Maria-Maren Sepper, toim. Finest Linguistics. Proceedings of the annual Finnish and Estonian conference of linguistics, Tallinn, May 6-7, 2004, 59-72. Tallinn: Tallinn University Press.

Koks, Helen (2006) Tingimuskonstruktsioonid tänapäeva eesti keeles. Käsikirjaline magistritöö. Tartu: Tartu Ülikool. Eesti keele õppetool.

Koptjevskaja-Tamm, Maria (1993) Nominalizations. Theoretical Linguistics Series. London: Routledge. 
Koptjevskaja-Tamm, Maria (1999) "Finiteness". Keith Brown, Jim Miller, toim. Concise Encyclopedia of Grammatical Categories, 146-149. New York: Elsevier.

Krifka, Manfred (1999) "Genericity”. Keith Brown, Jim Miller, toim. Concise Encyclopedia of Grammatical Categories, 169-171. New York: Elsevier.

Langacker, Ronald W. (1997) "Generics and habituals". Angeliki Athanasiadou, René Dirven, toim. On Conditionals Again, 191222. Amsterdam/Philadelphia: John Benjamins Publishing Company.

Nikolaeva, Irina (2007) "Constructional economy and nonfinite independent clauses". Irina Nikolaeva, toim. Finiteness. Theoretical and Empirical Foundations, 138-180. Oxford: Oxford University Press.

Noonan, Michael (1985) “Complementation”. Timothy Shopen, toim. Language Typology and Syntactic Fieldwork, 42-140. Cambridge: Cambridge University Press.

Pajunen, Anneli (2001) Argumenttirakenne. Asiaintilojen luokitus ja verbien käyttäytyminen suomen kielessä. Helsinki: Suomalaisen Kirjallisuuden Seura.

Penjam, Pille (2008) Eesti kirjakeele da- ja ma-infinitiiviga konstruktsioonid. (Dissertationes Philologiae Estonicae Universitatis Tartuensis 23.) Tartu: Tartu Ülikooli Kirjastus.

Plado, Helen (2008) „Adverbiaallausete funktsioonipõhine liigitus eesti keele tingimus- ja põhjuslause näitel“". Emakeele Seltsi aastaraamat 53 (2007), 122-145. Tallinn: Teaduste Akadeemia Kirjastus.

Sweetser, Eve E. (1990) From etymology to pragmatics. Metaphorical and cultural aspects of semantic structure. Cambridge: Cambridge University Press.

Thompson, Sandra A., Robert E. Longacre (1985) "Adverbial clauses". Timothy Shopen, toim. Language Typology and Syntactic Fieldwork, 171-234. Cambridge: Cambridge University Press.

Visapää, Laura (2008) Infinitiivi ja sen infiniittisyys. Tutkimus suomen kielen itsenäisistä A-infinitiivikonstruktioista. (Suomalaisen Kirjallisuuden Seuran Toimituksia 1181.) Helsinki: Suomalaisen Kirjallisuuden Seura.

Ylikoski, Jussi (2003) "Defining non-finites: Action nominals, converbs and infinitives". SKY Journal of Linguistics 16, 185-237. 
Helen Plado. Conditional Clauses with $d a$-infinitive Predicate in Estonian. This paper focuses on the conditional clauses with the predicate in the $d a$-infinitive. The paper provides answers to questions about the ways of expressing the hypothetical degree in such clauses; in which function can the conditional clause with $d a$-infinitive predicate be used and whether usage of the verb form, not marked by the categories of person, time or mood, marks the sentence as generic. The study also shows that conditional clauses with $d a$-infinitive predicate differ from the finite conditional clauses in several ways. The degree of hypotheticality of the sentence depends mainly on the predicate form of the main clause. If the predicate verb of the main clause is in the indicative form, the hypothetical degree of the sentence is low. If the predicate of the main clause is in the conditional form, the hypothetical degree of the sentence is often high. In addition to the mood of the predicate verb of the main clause, the hypothetical degree of the sentence can be influenced by other factors, e.g. the usage of certain adverbs or the past tense in the main clause. There are not many $d a$ infinite predicate content conditional clauses and no $d a$-infinitive predicate epistemic conditional clauses in the analysed data. The $d a$ infinitive predicate is most often used in conversational conditional clauses. The usage of the $d a$-infinitive predicate in content conditional clauses makes the whole sentence generic while in the case of conversational conditional clauses the sentence is still interpreted as nongeneric. The semantic subject of the $d a$-infinitive predicate is the indefinite person who is likely to participate in the speech act in case of the conversational conditional clause.

Keywords: Estonian, syntax, adverbial clause, conditional clause, infinitive, genericity 